\title{
Groundwater Depletion with Expansion of Irrigation in Barind Tract: A Case Study of Tanore Upazila
}

\author{
Md. Marufur Rahman*, A. Q. M. Mahbub \\ Geography and Environment, University of Dhaka, Dhaka, Bangladesh \\ Email: "marufurahman@yahoo.com
}

Received May 12, 2012; revised June 22, 2012; accepted June 30, 2012

\begin{abstract}
In this paper successive depletion of groundwater level with expansion of groundwater irrigation in Barind Tract has been discussed from mid 1960s to 2010 in the context of Tanore Upazila, which is located in severely drought prone area of northwest Bangladesh. After starting of groundwater irrigation in Bangladesh, it spread rapidly all over the country, and about $80 \%$ of agricultural land is now supplied irrigation from groundwater. Availability of irrigation in Barind Tract has revolutionized its agriculture, but groundwater level is successively falling all over the country due to excessive withdrawal, and this process is accelerating due to water withdrawal from major rivers by upstream countries. In northwestern part of Bangladesh groundwater depletion problem is severe because this part is free from seasonal flooding. Only source of recharging of groundwater aquifer in this area is rainfall, but rainfall is also lowest here among the country. In this context, this paper presents the change of groundwater level with the spreading of groundwater irrigation in Barind Tract. Hydrograph analysis, groundwater level mapping, groundwater depletion rate calculation are done from groundwater level observation well data of Bangladesh Water Development Board (BWDB) and Barind Multipurpose Development Authority (BMDA). Climatic condition is analyzed by calculation of rainfall deviation from the data of Bangladesh Meteorological Department (BMD). Focus Group Discussion (FGD) and interviews with farmers and experts of different branches are conducted to understand the nature of problems in the study area. Agricultural pattern, cropping intensity ( $262 \%$ in study area and national intensity is $180 \%)$, methods of cultivation, crop variety and yields all show a positive change after starting of groundwater irrigation in mid 1980s, but water level is continuously lowering at the rate of $1.37 \mathrm{ft} / \mathrm{y}$ in wet season and $0.72 \mathrm{ft} / \mathrm{y}$ in dry season. Water is the main input for agriculture but successive depletion of groundwater level can be a serious problem for water stressed Barind Tract. Crop diversification, artificial recharging, increasing dependency on surface water, increasing irrigation efficiency, rainwater harvesting etc., can be option for the area.
\end{abstract}

Keywords: Groundwater Depletion; Irrigation; Barind Tract; Tanore

\section{Introduction}

Globally, irrigation is responsible for more than $65 \%$ of all fresh water withdrawals. At present, one quarter of world's irrigated land is supplied by groundwater and $75 \%$ of these lands are located in Asia [1]. Agriculture in Bangladesh was entirely dependent on surface water and monsoon rainfall prior to 1970s [2]. Now in Bangladesh $79.1 \%$ lands are supplied water in boro season from underground source [3]. Agricultural land in Bangladesh was irrigated by traditional means up to 1950s without any institutional base and was institutionalized with the formation of East Pakistan Water and Power Development Authority (Now, BWDB) in 1959 [4]. Bangladesh Agricultural Development Corporation (BADC), the then East Pakistan Agricultural Development Corporation (EPADC) was created in 1961 and act as the main

${ }^{*}$ Corresponding author. organization for the expansion of both groundwater and surface water irrigation [5].

Barind Tract is a physiographic unit located in northwestern part of Bangladesh having gross area of $7727 \mathrm{sq}$ $\mathrm{km}$ [6]. Geographically this unit lies between $24^{\circ} 20^{\prime} \mathrm{N}$ and $25^{\circ} 35^{\prime} \mathrm{N}$ latitudes and $88^{\circ} 20^{\prime} \mathrm{E}$ and $89^{\circ} 30^{\prime} \mathrm{E}$ longitudes. Barind Tract made up of Pleistocene Alluvium also known as Older Alluvium and floored by reddish brown, sticky Pleistocene sediment; Madhupur Clay [7]. Pleistocene Dupi Tila Sand act as aquifer in Barind Tract [8]. Barind Tract was excluded during 3000 Deep Tube Well (DTW) installation programme of BADC in North-west Irrigation Project considering as low potential area for groundwater development [9]. Groundwater development occurs in Barind with the formation of Barind Integrated Area Development Project (BIADP) in 1985 under BADC and later with formation of Barind Multipurpose Development Authority (BMDA) in 1992 [10]. 
Tanore is an upazila of Rajshahi District located in northwest Bangladesh (Figure 1). This upazila is located between $24^{\circ} 28^{\prime} \mathrm{N}$ and $24^{\circ} 44^{\prime} \mathrm{N}$ latitudes and between $88^{\circ} 24^{\prime} \mathrm{E}$ and $88^{\circ} 39^{\prime} \mathrm{E}$ longitudes. Physiographically Tanore consist of Barind Tract (81.8\%), Old Gangetic Floodplain (3\%) and Tista Floodplain (4.8\%) others including homestead, wetland, ponds, river $(10.4 \%)$ in respect of total area [11]. Textural class of soil is Clay loam 46\%, Loam 35\%, and Clay 8\% [12]. With the expansion of irrigation in Tanore Upazila from mid 1980 s, a revolutionary change is occurred in its agricultural sector. Introduction of High Yielding Varieties (HYV) paddy with transforming from broadcasted to transplanted cultivation, increase of yields all bring by groundwater irrigation. Single cropped agricultural land now producing three crops in one agricultural year after starting of groundwater irrigation. Cropping intensity of Tanore is now $262 \%$, much higher than national cropping intensity of Bangladesh $180 \%$ [13].

Groundwater recharging in Bangladesh is mainly occur by monsoon rainfall and flooding. Due to high elevation of Barind, it is located in flood free zone. So, only source of groundwater recharging in this area is rainfall, but lowest amount of rainfall occur in northwestern part of Bangladesh and it is also a very severely drought prone area. Moreover, thick sticky clay surface of Barind

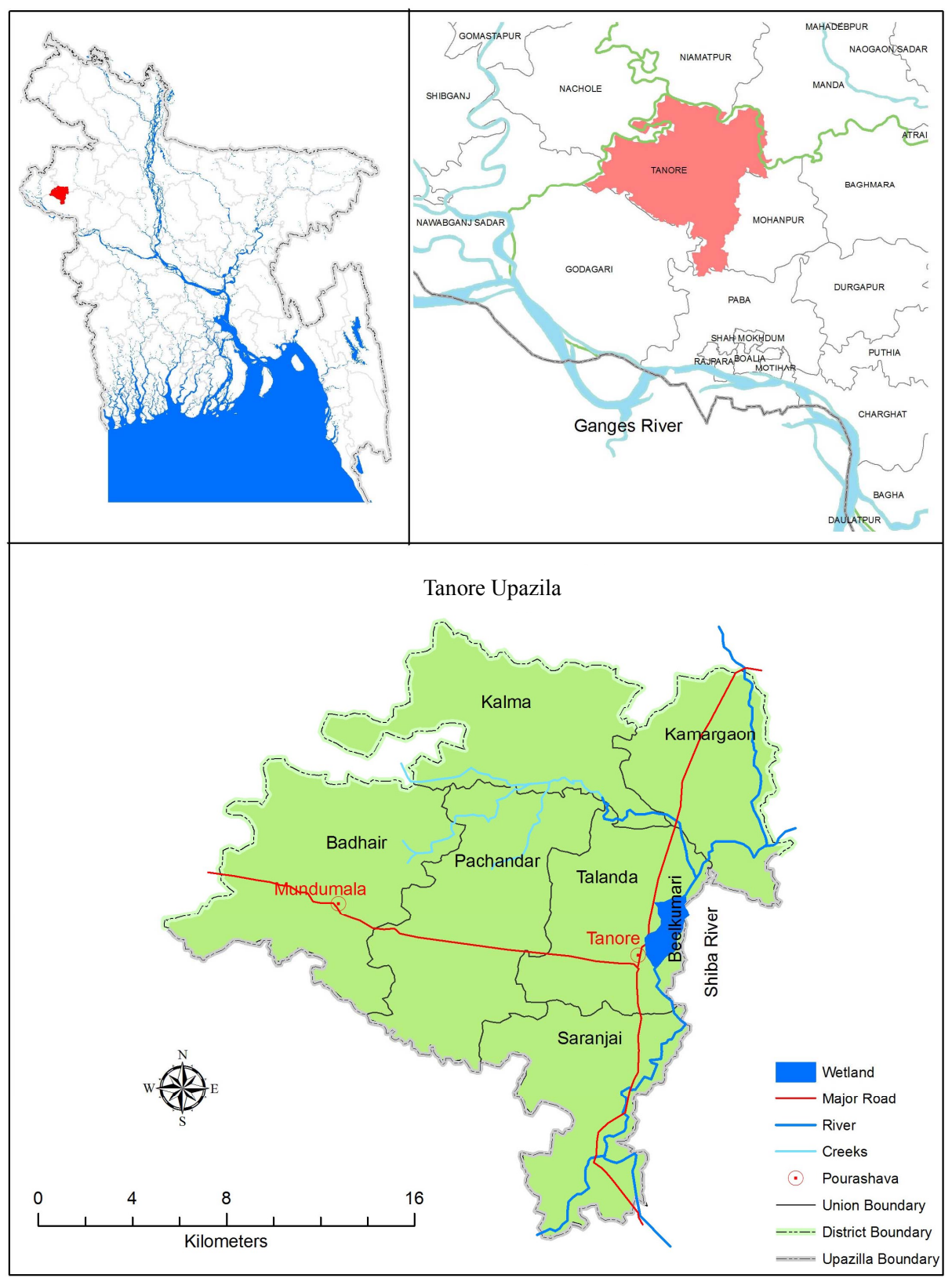

Figure 1. Location map of study area. 
Tract act as aquitard which impede groundwater recharging and increase surface runoff. As a result, groundwater level in this part is successively falling by years with increasing withdrawal of water for irrigation.

\section{Methods}

Secondary data is mainly used for this study. The study is based on groundwater monitoring piezometer data of Bangladesh Water Development Board (BWDB) from 1966-2010 and monitoring well of Barind Multipurpose Development Authority 1986-2010 (BMDA) (see Figure 2). Rainfall data is collected from Bangladesh Meteorological Department (BMD). Lithology of the study area is studied from borehole logs collected from BMDA.
Fourteen piezometer data in and around Tanore Upazila are used for mapping of contour elevation of groundwater level of study area. Groundwater levels are referenced to a common datum (Public Works Datum, PWD) which was originally set to the mean sea level (msl) with a vertical error of $\pm 0.45 \mathrm{~m}$ during the Great Trigonometric Survey in the Indian Subcontinent throughout the nineteenth century [1]. Groundwater depletion rate is calculated from the data of BMDA and BWDB monitoring well. Mapping software ArcGIS 9.3.1 is used for mapping. Personal interview with different expert groups and Focus Group Discussion (FGD) in the study area with the local people are conducted to understand the nature of the problem.

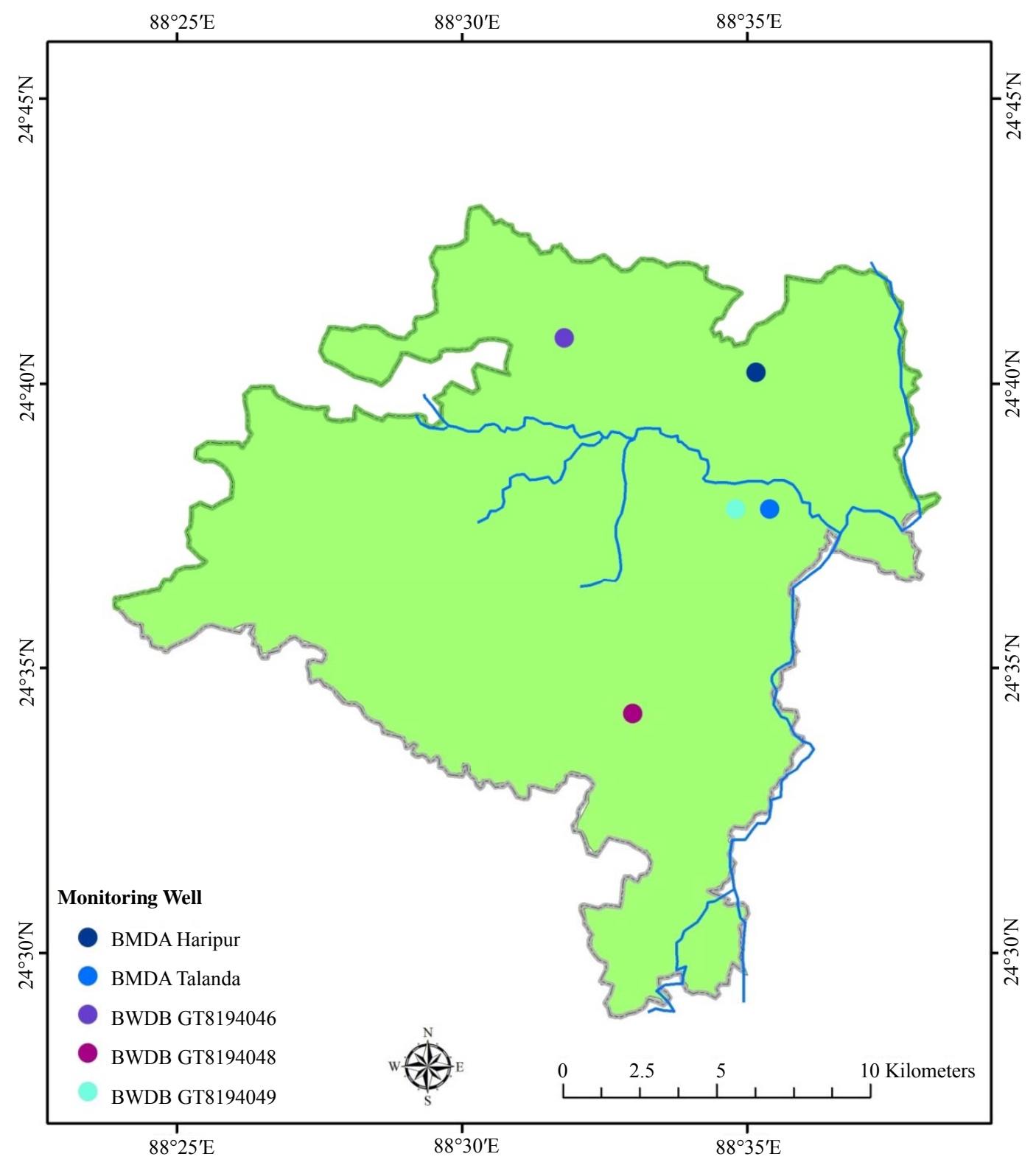

Figure 2. Location of groundwater level monitoring well in Tanore Upazila. 


\section{Result and Discussion}

\subsection{Hydrograph Analysis}

Long term groundwater level trend is observed by analysis of hydrograph from groundwater observation well data. For analysis of long term trends of groundwater level of Tanore Upazila, two observation wells of BWDB and two observation wells of BMDA are used. The data of BWDB's wells used from 1966-2010 and data of BMDA wells from 1987-2010. All four observation wells of two organizations of Tanore Upazila are showing a successive depleting trend of groundwater level over time. In Bangladesh groundwater level rise in wet season (due to monsoon rain and flooding in main river) and reach in maximum level in August to September and after the wet season it start to fall and reach in minimum level in the pre-monsoon months of April to May. In hydrograph with seasonal fluctuation the declining trend of groundwater level in the study area is very clear.

The elevation of study area is increase from eastern to western side and the thickness of clay and depth of aquifer is also show same nature as a result depth of groundwater level is vary from eastern to western side. Groundwater level found in maximum depth from the surface ground in western side and minimum depth in eastern side, but it is clear that in all area groundwater table is continuously going down or elevation of groundwater level from mean sea level is continuously decreasing although still it found above the mean sea level (msl) (see Figure 3).

Kamargaon observation well of BMDA is located in

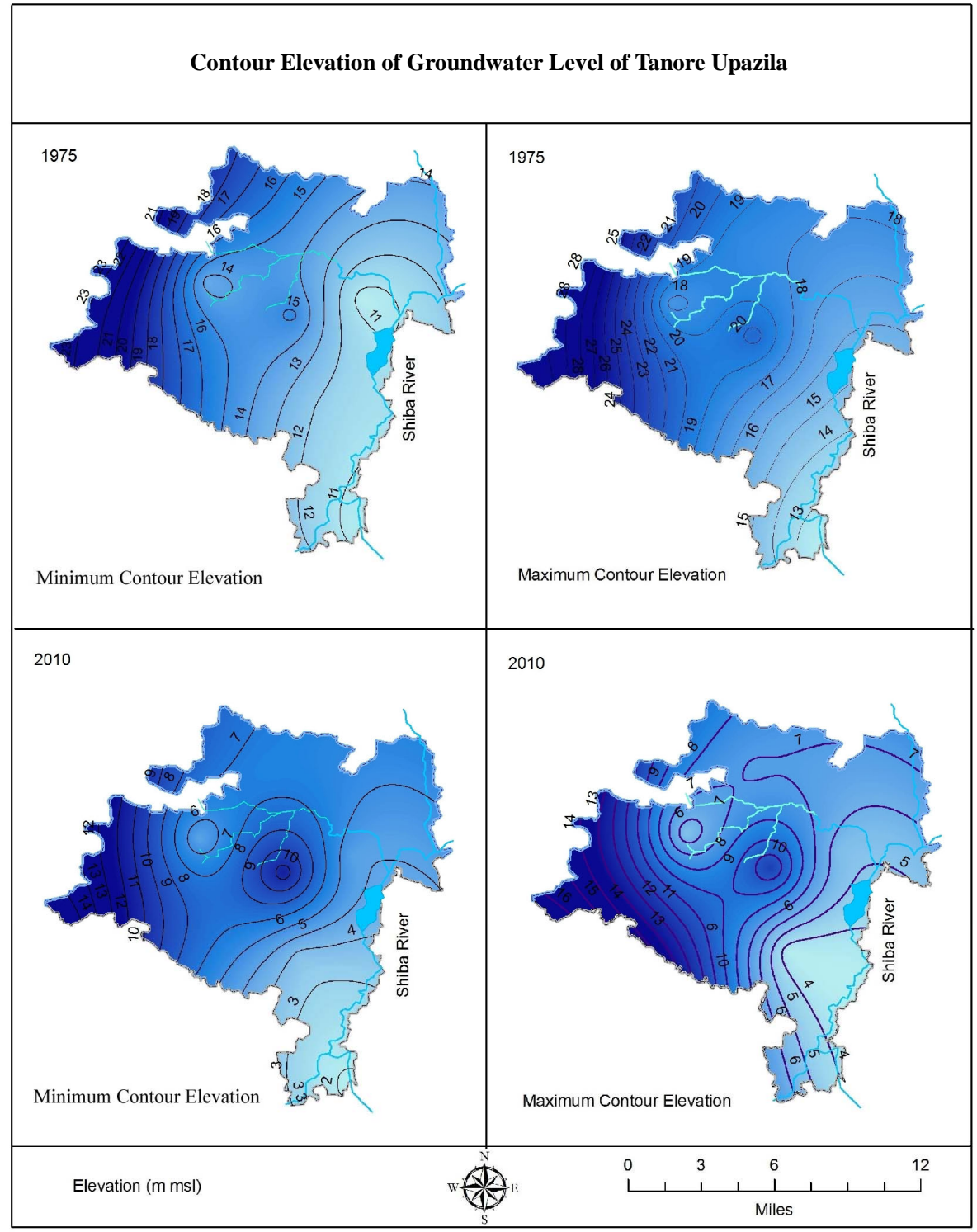

Figure 3. Contour elevation of groundwater level of Tanore Upazila. Data source: BWDB. 
Haripur of Kamargaon Union where clay thickness is about 25 - $30 \mathrm{ft}$ and sand aquifer located below $20-30 \mathrm{ft}$ from surface. Hydrograph of Kamargaon Union showing groundwater level fluctuation from 1986-2010. Data is collected in fifteen days interval in $15^{\text {th }}$ and last day of month. Hydrograph in Figure $\mathbf{4}$ depict both seasonal fluctuation and long term trends of water level in the area. In 1986 seasonal fluctuation occur in between $5-23 \mathrm{ft}$ which stands in $29-54 \mathrm{ft}$ in the year of 2009. The difference between maximum and minimum water level in one season was $2.67 \mathrm{ft}$ (2010). Hydrograph show a declining trend of groundwater level which starts to decline in a rapid rate after 2002 .

Talanda observation well of BMDA is in Talanda Mouza and located very close to River Shiba and Beelkumari. Hydrograph in Figure 5 depict the groundwater level of Talanda from fifteen July 1986 to thirty June 2011. Interval of data collection is similar to Haripur observation well of BMDA and it is fifteen days and in fifteenth and last day of month, twenty four observation in a year. Clay thickness and aquifer depth are varied in Talanda Union. Thickness of clay layer of observation well is about $20 \mathrm{ft}$ and below $20 \mathrm{ft}$ from surface sand aquifer is located. Hydrograph in Figure 5 present both long term trend of groundwater level and seasonal fluctuation. In 1987 seasonal fluctuation of groundwater

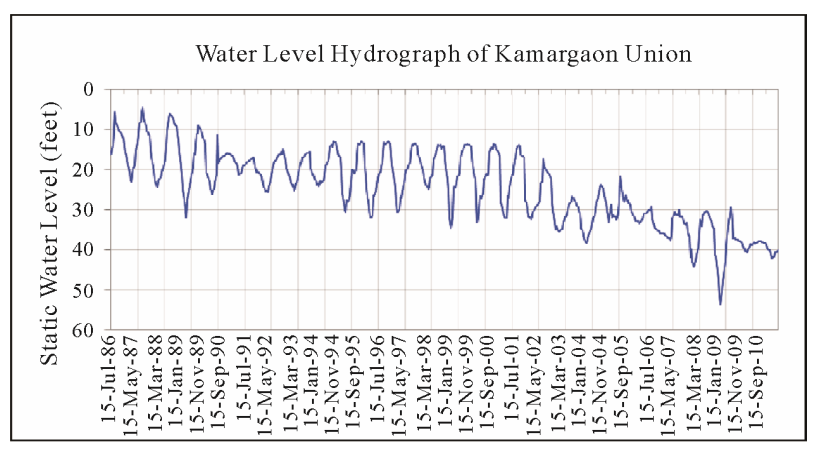

Figure 4. Water level hydrograph of Kamargaon Union, Tanore. Data source: BMDA (Mouza: Haripur, J.L. No-236, Plot No-211).

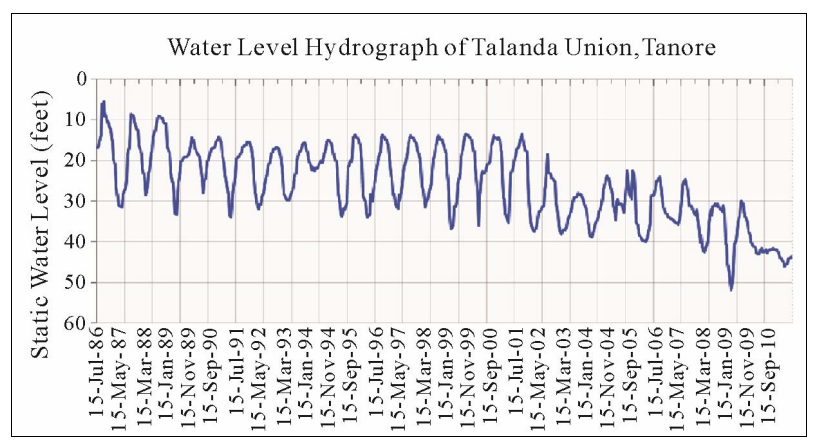

Figure 5. Water level hydrograph of Talanda Union, Tanore. Data source: BMDA (Mouza: Talanda, J.L. No-224, Plot No-1138). occur $8.50-31.54 \mathrm{ft}$ and it standed $41.67-42.83 \mathrm{ft}$ in 2010. Fluctuation of water level in 2010 was very small because low rainfall in wet season. Recorded rainfall from BMD's Rajshahi station was only $792 \mathrm{~mm}$.

Two observation well of BWDB is used in hydrograph analysis of groundwater level of Tanore Upazila. New well ID of BWDB well is GT8194046 and GT8194048 and old ID was RJ039 and RJ086 respectively. Reading interval and observation well type of BWDB both is different from BMDA observation well. Reading interval is seven days in BWDB well. In collected data reading is taken every week but not in a fixed date like BMDA and data missing is a common problem. BWDB wells are used only for groundwater level monitoring purpose, whereas BMDA wells are used both for irrigation and water level monitoring. Static water level is collected from BMDA wells for monitoring of groundwater level. Unit of BWDB's collected data is meter, whereas BMDA collect data in feet.

From $14^{\text {th }}$ February 1966 to $18^{\text {th }}$ October of 2010 data of well GT8194046 is used for hydrograph analysis. From $14^{\text {th }}$ June 1971 to 1972 data of this well was not available, and the reason is easily understandable. The War of Liberation occurs in 1971, as a result data collection was interrupted and it was again started from first January 1973. Prior reading was collected from dug well and later it was replaced by piezometer. Hydrograph in Figure 6 show that groundwater level fluctuation was almost stable till 1978 and after 1978 fluctuation level is increased but after 1983 the groundwater level decline rapidly and the sharp negative trend is observed till present.

Data from $12^{\text {th }}$ December 1966 to $11^{\text {th }}$ October 2010 of BWDB's well GT8194048 is used in hydrograph of Figure 7. Data was unavailable from $5^{\text {th }}$ April 1971 to October of 1972 due to Liberation War and from November 1972 data collection was again started. After 1980 depletion trend is observed and after 1994 groundwater level deplete rapidly. Spread of irrigation in Tanore Upazila occurs in 1980s which is the main factor of groundwater level depletion.

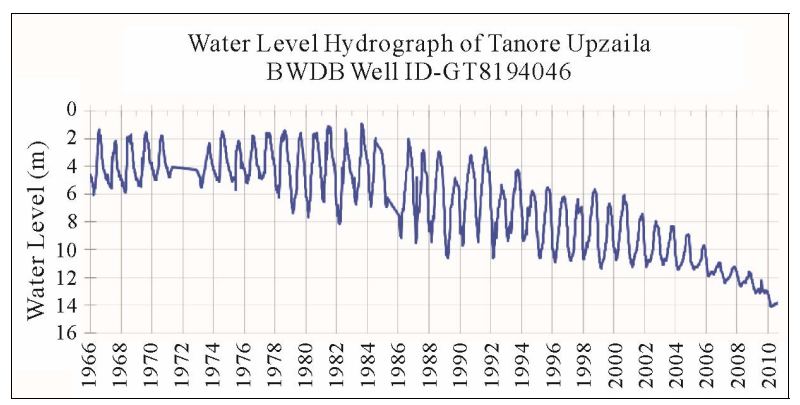

Figure 6. Water level hydrograph of Tanore Upazila. Data source: BWDB. 


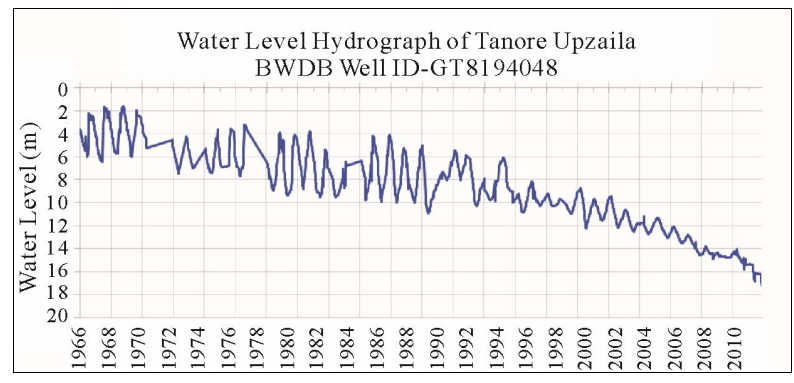

Figure 7. Water level hydrograph of Tanore Upazila. Data source: BWDB.

\subsection{Groundwater Development and Water Level}

Groundwater irrigation was started in Tanore Upazila in 1970s and spread after formation of Barind Integrated Area Development Project (BIADP) in 1985 [10]. First time, irrigation started in eastern part (see Figure 8) and western part was avoided due to high depth of aquifer (70 - $90 \mathrm{ft}$ below the surface), later irrigation spread all parts of upazila with the formation of Barind Multipurpose Development Authority (BMDA) in 1992.

Groundwater level is continuously going down every year. Figure 9 shows the relationship between deep tube well development and water level in dry season from 1966 to 2010. Graph show a clear relationship between water level and development of DTW over time. With increasing number of deep tube wells, every year the rate of depletion of groundwater level is accelerating in dry season. From 1966-1975 hydrograph show almost no change in groundwater level. In 1975 number of deep tube wells was only 5 and from 1986 number is increasing in an accelerating rate and groundwater level also starts to deplete rapidly from 1986. According to groundwater observation well GT8194046 of BWDB minimum water level was fluctuate in between $6.08 \mathrm{~m}$ to $6.86 \mathrm{~m}$ from 1966 to 1984, and total number of deep tube wells was 77 in 1984. In 1986 minimum water level reached in $9.03 \mathrm{~m}$ and number of deep tube wells was 122 . In 2010 water level reaches in $14.09 \mathrm{~m}$ from 1966's $6.08 \mathrm{~m}$ and number of DTWs cross 500 and huge number of shallow tube wells are also come in operation (which known as mini-deep in the study area) by private sector in the meantime.

Figure 10 shows relationships between maximum water level and annual rainfall. Annual rainfall data is used from Rajshahi station of BMD from 1979 to 2010. From the graph it is clear that although rainfalls show a regular pattern, but maximum water level elevation is continuously going down or depth of water level increasing from surface. In 1981 annual rainfall was $2241 \mathrm{~mm}$ and water level was in $1.12 \mathrm{~m}$ depth from surface and in 2007 annual rainfall was $2018 \mathrm{~mm}$ but groundwater level reached in $11.22 \mathrm{~m}$ below surface ground. Water level of

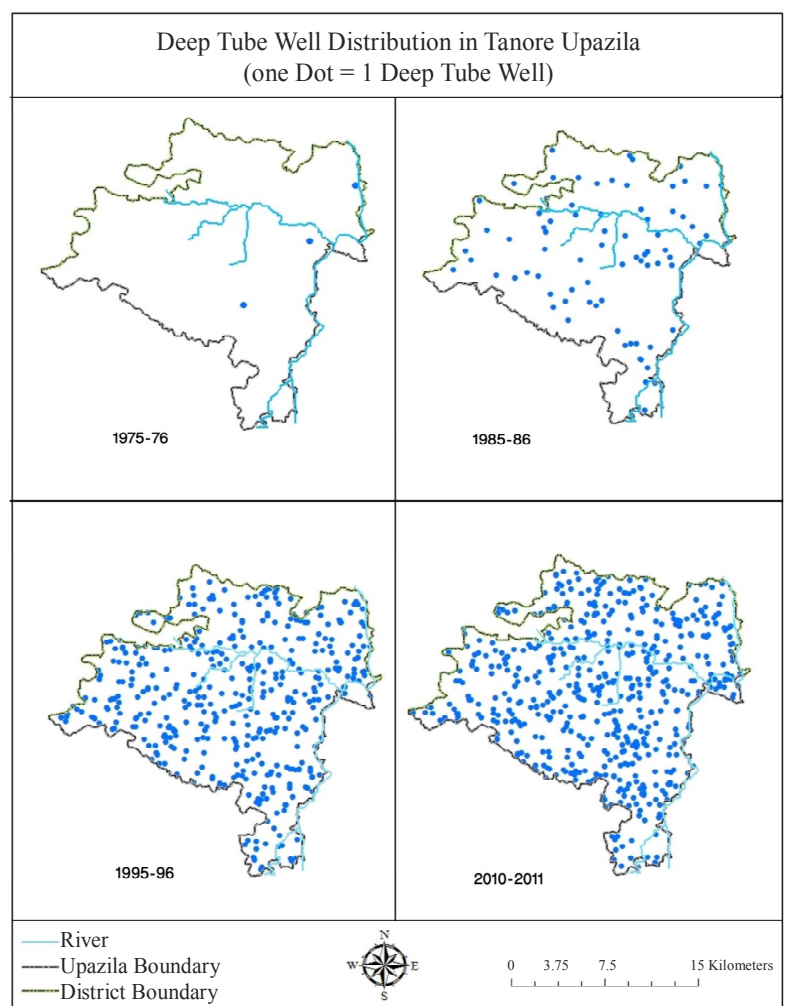

Figure 8. Deep tube well distribution for irrigation in Tanore Upazila over time. Data source: BMDA.

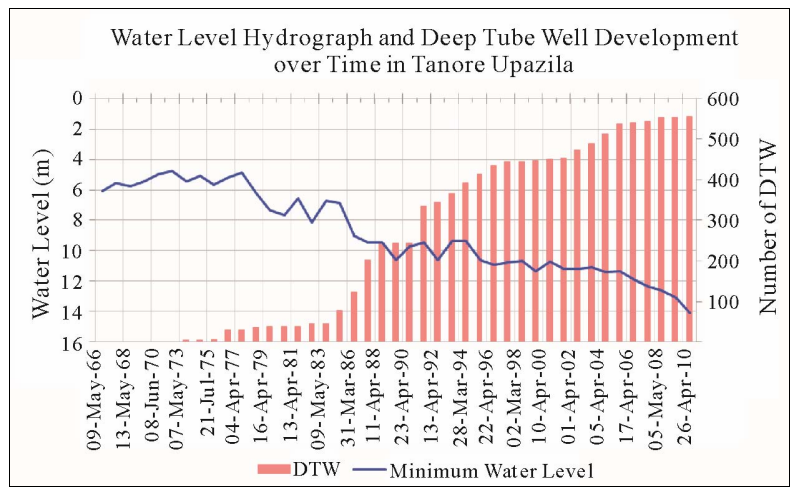

Figure 9. Water level hydrograph and deep tube well development over time in Tanore Upazila. Data source: BMDA, BWDB (Well ID-GT8194046).

well GT8194046 was stayed 1.35 to $1.95 \mathrm{~m}$ till 1984 (1.35 m in 1966 and $1.95 \mathrm{~m}$ in 1984) in wet season. In 1986 water level reached in $2.03 \mathrm{~m}$ and in 2010 it was in $13.77 \mathrm{~m}$ below surface. In 1992 and 2010 annual rainfall was lowest $843 \mathrm{~mm}$ and $792 \mathrm{~mm}$ and water level was 5.3 $\mathrm{m}$ and $13.77 \mathrm{~m}$ respectively. So, recharging in wet season is overruled by withdrawal of water all year round in study area.

Figure 8 shows the spreading of deep tube well in study area over time and Figure 3 shows the change in groundwater level elevation in the meantime. 
Figure 11 shows rainfall deviations from normal annual rainfall from 1979-2010. It also depicts a regular positive and negative anomaly over time, but maximum groundwater level show continuous negative trend (Figure 10).

Due to continuous depletion of water level many hand tube wells suffer layer failure problems and abandoned or replaced by tap (Figure 12). Some hand tube wells are also abandoned for availability of tap line not for layer failure. Tap is much convenient than hand tube well which need muscle power during water withdrawal, and when groundwater layer stay at minimum level elevation (msl) in dry season water withdrawal become very tedious job by hand tube well for drinking and other domestic purposes. Water supplied to tap from irrigation deep tube well through overhead tank for drinking purpose. But people now use tap water for drinking and for all other domestic and household uses. Ponds and other sources of surface water are now used only for cultivation of fish and animal birds rearing.

\subsection{Groundwater Depletion Rate of Tanore}

According to five piezometers of BWDB, the groundwa-

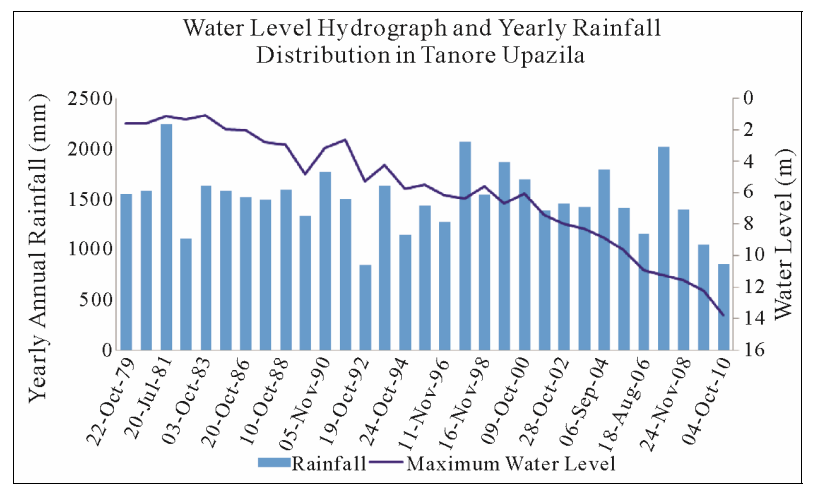

Figure 10. Water level hydrograph and yearly rainfall distribution in Tanore Upazila. Data source: BMD, BWDB (Well ID-GT8194046).

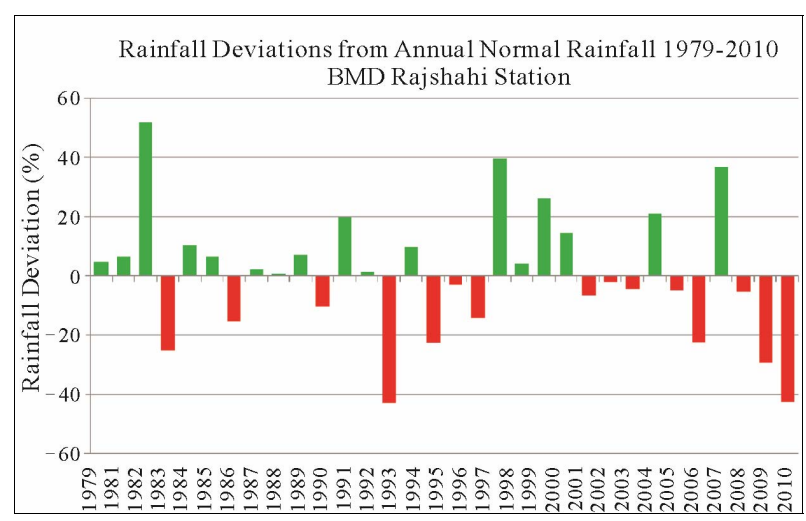

Figure 11. Rainfall deviations from annual normal rainfall in study area.

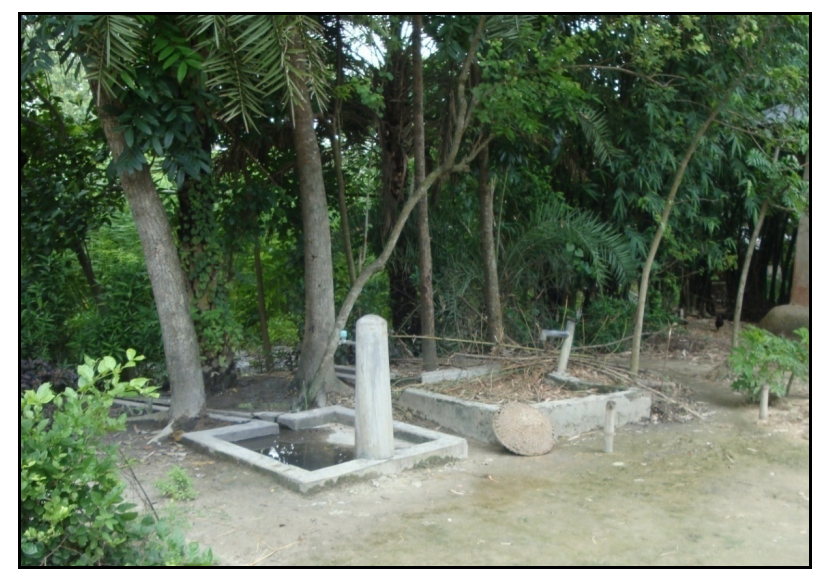

Figure 12. Abandonment of hand tube well due to water layer failure in study area.

ter level of Tanore Upazila yet found above the mean sea level but depleting in an accelerating rate. The groundwater depletion rate in Tanore is calculated from three piezometers data of BWDB and two monitoring wells data of BMDA (see Figure 2).

\subsubsection{Depletion Rate in Wet Season}

From three BWDB monitoring wells data groundwater depletion rate in wet season when water table stayed at minimum depth from surface and maximum elevation from mean sea level (msl) is higher than one $\mathrm{ft}$ per year. The piezometer GT8194046 show depletion rate $1.54 \mathrm{ft} / \mathrm{y}$, GT8194048 and GT8194049 show rate of depletion 1.15 $\mathrm{ft} / \mathrm{y}$ and $1.26 \mathrm{ft} / \mathrm{y}$ respectively (see Table 1).

In all three monitoring wells calculation are done from the maximum water level elevation (msl) of 1983 and 2010.

Rate calculation from BMDA monitoring well is done from 1987 and 2010 data. One monitoring well of BMDA is located in Talanda Union and other is in Haripur of Kamargaon Union (Figure 2). Calculated depletion rate of both monitoring wells are higher than one $\mathrm{ft}$ per year in wet season and the rate is same, $1.44 \mathrm{ft} / \mathrm{y}$. Average rate from five monitoring wells of two organizations in wet season (depletion rate of maximum water level elevation) is $1.37 \mathrm{ft} / \mathrm{y}$. It is clear that the recovery rate is lower than the withdrawal rate as a result the groundwater table is depleting in wet season in an alarming rate.

\subsubsection{Depletion Rate in Dry Season}

Depletion rate of minimum water level elevation (msl) of Tanore Upazila is also calculated from the same five monitoring wells of two organizations used in depletion rate calculation of maximum water level elevation (see Table 2). In dry season water table fall and reach in maximum depth from surface and the elevation stayed minimum from mean sea level. 
Table 1. Calculation of depletion rate of maximum water level elevation (wet season) in study area.

\begin{tabular}{ccccc}
\hline Name of the Well & Water Level (ft) & Water Level (ft) & Difference (ft) & Rate of Depletion (ft/y) \\
\hline BWDB Well ID & $\mathbf{1 9 8 3}$ & $\mathbf{2 0 1 0}$ & & \\
GT8194046 & 3.54 & 45.17 & 41.63 & 1.54 \\
GT8194048 & 22 & 53.04 & 31.04 & 1.15 \\
GT8194049 & 8.98 & 42.96 & 33.98 & 1.26 \\
BMDA Well & $\mathbf{1 9 8 7}$ & $\mathbf{2 0 1 0}$ & 33.17 & 1.44 \\
Talanda & 8.50 & 41.67 & 33.16 & 1.44 \\
Kamargaon & 4.67 & 37.83 & & 1.37 \\
\hline
\end{tabular}

Data source: BWDB, BMDA.

Table 2. Calculation of depletion rate of minimum water level elevation (dry season) in study area.

\begin{tabular}{ccccc}
\hline Name of the Well & Water Level (ft) & Water Level (ft) & Difference (ft) & Rate of Depletion (ft/y) \\
\hline BWDB Well ID & $\mathbf{1 9 8 3}$ & $\mathbf{2 0 1 0}$ & & \\
GT8194046 & 22 & 46.22 & 24.22 & 0.89 \\
GT8194048 & 31 & 53.04 & 22.04 & 0.82 \\
GT8194049 & 26.33 & 43.95 & 17.62 & 0.65 \\
BMDA Well & $\mathbf{1 9 8 7}$ & $\mathbf{2 0 1 0}$ & 11.25 & 0.49 \\
Talanda & 31.58 & 42.83 & 17.33 & 0.75 \\
Kamargaon & 23.17 & 40.50 & & 0.72 \\
\hline
\end{tabular}

Data source: BWDB, BMDA.

Depletion rate of minimum water level elevation calculated from 1983-2010 using three piezometers of BWDB is below one $\mathrm{ft} / \mathrm{y}$. From the well GT8194046 calculated depletion rate is $0.89 \mathrm{ft} / \mathrm{y}$ and according to well GT8194048 and GT8194049 the rate is $0.82 \mathrm{ft} / \mathrm{y}$ and $0.65 \mathrm{ft} / \mathrm{y}$ respectively in dry season. Two BMDA wells also show depletion of groundwater level in dry season and the rate of depletion is $0.49 \mathrm{ft} / \mathrm{y}$ in Talanda well and $0.75 \mathrm{ft} / \mathrm{y}$ in Haripur well of Kamargaon Union. The well of Talanda is showing lowest depletion rate in dry season may be due to very close location from the River Shiba and wetland Beelkumari which give this area a higher recharging rate than all other parts of the study area located in a distant location from wetland and river (see Figure 2). From five wells of two organizations, average value of rate of depletion in dry season is $0.72 \mathrm{ft} / \mathrm{y}$ in Tanore Upazila.

From the groundwater monitoring well data, average depletion rate of maximum water level elevation is 1.37 $\mathrm{ft} / \mathrm{y}$ and average depletion rate of minimum water level elevation in Tanore is $0.72 \mathrm{ft} / \mathrm{y}$. Depletion rate in dry and wet season is different. Rate of depletion in wet season is higher than the rate in dry season. From this nature of depletion it can be stated that groundwater level in the study area is depleting in an accelerating rate from year to year.

Recharging of groundwater occur mainly in between four monsoon months June-September (about 80\% of rainfall occur in monsoon period in Bangladesh) and replenishment of water level by annual rainfall is overruled by annual increasing amount of withdrawal. As a result, all five wells of two organizations located in different parts of the upazila are showing depleting nature of groundwater level.

The average value of yearly maximum rate of depletion and minimum rate of depletion in Tanore Upazila from five monitoring wells of two different organizations spread over different parts of the study area is $1.04 \mathrm{ft} / \mathrm{y}$.

\section{Conclusions}

Result shows that both maximum and minimum groundwater levels of the study area are depleting. Average de- 
pletion rate of maximum water level $1.37 \mathrm{ft} / \mathrm{y}$ is much higher than average depletion rate of minimum water level, which is $0.72 \mathrm{ft} / \mathrm{y}$. Agriculture is very important in the context of Bangladesh because to feed a huge number of population. Agricultural sector also provide employment to a huge number of unskilled and semi-skilled labors so in this context it is also important. Due to expansion of groundwater irrigation cropping intensity of the study area have crossed even national level, but it is also the prime reason for groundwater depletion of the study area. Intrusion of saline water is not an issue for the area which located in a distant location from the sea and for high thickness of clay layer, land subsidence risk is also comparatively low due to groundwater depletion. Excessive withdrawal is lowering water level in the area successively and surface water bodies can be severely affected by this process.

Crop diversification from water consuming crop (paddy) to less water consuming crops (vegetables, fruits etc.), artificial recharging, increasing dependency on surface water, increasing irrigation efficiency including application of Alternate Wetting and Drying (AWD) method, rainwater harvesting etc, can be option for the study area.

\section{Acknowledgements}

The authors are thankful to Professor Dr. Kazi Matin U. Ahmed, Department of Geology of University of Dhaka; Barind Multipurpose Development Authority (BMDA) and Bangladesh Meteorological Department (BMD) for financial and other supports.

\section{REFERENCES}

[1] M. Shamsudduha, R. G. Taylor, K. M. Ahmed and A. Zahid, "The Impact of Intensive Groundwater Abstraction on Recharge to a Shallow Regional Aquifer System: Evi- dence from Bangladesh," Hydrogeology Journal, Vol. 19, No. 4, 2011, pp. 901-916. doi:10.1007/s10040-011-0723-4

[2] UNDP (United Nation Development Programme), "Groundwater Survey: The Hydro-Geological Conditions of Bangladesh," Technical Report, UNDP, New York, 1982, DP/UN/BGD-74-009/1.

[3] BADC (Bangladesh Agricultural Development Corporation), "Minor Irrigation Survey Report 2009-10," BADC, Dhaka, 2010, p. 3.

[4] A. M. Ali, "Fundamentals of Irrigation and On-farm Water Management," Springer-Verlag New York Inc., New York, Vol. 1, 2011, p. 18.

[5] IBRD (International Bank for Reconstruction and Development) IBRD-IDA Tube Well Project, EPADC, East Pakistan, 1970, Vol. PA-49a, Annex 11, p. 1.

[6] K. B. S. Rasheed, "Bangladesh: Resource and Environmental Profile," A.H. Development Publishing House, Dhaka, 2008.

[7] K. M. Ahmed, "Barind Tract," 2006. http://www.banglapedia.org/httpdocs/HT/B_0309.HTM

[8] K. M. Ahmed, M. A. Hossain, "Groundwater," 2006. http://www.banglapedia.org/httpdocs/HT/G_0209.HTM

[9] BMDA (Barind Multipurpose Development Authority), "Borandro Authority Past-Present," BMDA Rajshahi, 2006, p. 35.

[10] BMDA (Barind Multipurpose Development Authority), 2011. http://www.bmda.gov.bd/

[11] SRDI (Soil Resource Development Institute), "Upazila Land and Soil Resource Utilization Guide: Tanore, Rajshahi," SRDI, 2000, p. 10.

[12] SRDI (Soil Resource Development Institute), "Land and Soil Statistical Appraisal Book of Bangladesh," SRDI, Dhaka, 2010, p. 155.

[13] BBS (Bangladesh Bureau of Statistics), "Cropping Intensity of Bangladesh," 2010. http://www.brri.gov.bd/info_services/rice_database/Crop ping\%20Intensity.pdf 